\title{
Fuelling fire sales? Prudential regulation and crises: evidence from the Italian market
}

\author{
Alessandro Leardi ${ }^{1}$ (D) \\ Accepted: 11 June 2021 / Published online: 5 August 2021 \\ (C) Academy of Economics and Finance 2021
}

\begin{abstract}
The ECB announcement to reduce capital requirements for market risk to smooth pro-cyclicality, published in April 2020, is a good starting point to discuss the impact of regulation on individual banks on the stability of the whole banking and financial system.

A large number of theoretical articles and a few empirical papers back the existence of an amplification effect on market volatility caused by the use of risk management measures (e.g. value-at-risk, VaR, for market risk) for regulatory purposes. However, to the best of my knowledge, no paper has empirically investigated the direct relation between the level of tightness of VaR risk limits and market volatility.

In this article, I show that market volatility is positively related to past values of the measure of the tightness of the market risk limit, with an overshooting process of adjustment toward equilibrium. The analysis is limited to Italy. The empirical results, based on a unique dataset of $\mathrm{VaR}$ values and on other publicly available market data, are in line with the theoretical findings and are novel empirical evidence. They open the way to additional research on how to manage the channels of transmission of the amplification and overshooting effects from the risk management measure to systemic variables, to avoid unintended consequences of the application of individual supervision measures on the whole system.
\end{abstract}

Keywords Value-at-risk $\cdot$ Pro-cyclicality $\cdot$ Regulation $\cdot$ Vector auto-regression JEL classification $\mathrm{G} 01 \cdot \mathrm{G} 11 \cdot \mathrm{G} 18 \cdot \mathrm{G} 21 \cdot \mathrm{G} 28$

The views expressed in this paper should be referred only to the author and not to the Institution with which he is affiliated.

Alessandro Leardi

alessandro.leardi@bancaditalia.it

1 Banca D’Italia, Via Cordusio, 5 20123, Milan, Italy 


\section{Introduction}

In April 2020, the banking supervision of the ECB announced a temporary reduction of capital requirements for market risk to respond to the extraordinary levels of volatility recorded in financial markets since the outbreak of the coronavirus (Covid-19). The decision is aimed at smoothing pro-cyclicality and maintaining banks' ability to provide market liquidity and to continue market-making activities (ECB - European Central Bank, 2020).

The policy stance of the supervisor was clear; however, no reference to theoretical model or empirical evidence was published along with the decision.

From a policy point of view, the opinion about regulatory measures based on risk management techniques (such as VaR) has changed over time. In 2006, the Chairman of the Federal Reserve Bank (Fed), Ben Bernanke, highlighted the importance of modern risk management as a central element of good supervisory practice and encouraged the industry to push forward the risk management frontier (Bernanke 2006). Just a few years later, in 2010, after the beginning of the financial crisis, Janet Yellen, Chair of the Fed from 2014, said that "methods of modern risk management may have intensified the cycle...because of their reliance on metrics such as value at risk that are highly sensitive to recent performance, especially volatility. In good times, volatility declines, and value at risk along with it. This pattern generated a pro-cyclical willingness to take on risk and leverage, amplifying and propagating the boom and bust cycle. The vicious cycle of a collapse of confidence, asset fire sales, evaporation of liquidity, and a deleveraging free fall was the mirror image of the manic mortgage market that preceded it" (Yellen 2010). Hence, in the four years between Bernanke's speech and Yellen's one, the opinion on risk management techniques, including the use of quantitative measures of risk such as VaR, changed radically. From crucial methods for economic stability and the main contributors to the decline of volatility (Panetta et al. 2006), they became a quasi-evil mechanism of depression which contributed to the worsening and deepening of the crisis (Bernanke 2008, Financial Stability Forum 2008, Senior Supervisors Group 2008).

From the theoretical side, academic literature has underlined the pro-cyclical effects of VaR constraints, which amplify the impact of shocks and affect market volatility (Adrian and Shin 2010, 2013, Danielsson 2010). Furthermore, Danielsson et al. (2001) claimed that the use of value at risk could have induced crashes when they would not have otherwise occurred. For some researchers, the main channel of transmission of the amplification effect, in a VaR-constrained framework, is the adjustments of the expected returns and covariances of the investors and the related increase to risk aversion caused by the VaR constraint (Danielsson et al. 2004).

From the empirical point of view, as mentioned above the evidence of the procyclical effects of capital requirements for market risk is poor and is in favour of the existence of the amplification effect described in the theoretical literature (Adrian and Shin 2010).

This work provides empirical evidence of pro-cyclicality of market risk prudential measures, by using a unique dataset of value at risk (VaR) values for 
Italian banks. In details, I show empirically that the increasing tightness of the value at risk constraint amplifies the instability of the financial market; therefore, the recent decision of the ECB to reduce capital requirement for market risk goes in the proper direction of containing pro-cyclicality.

To the best of my knowledge, no empirical proof of this pro-cyclical relation has been given so far. The main difficulties of such empirical proof are related to data availability and possible reverse causality or endogeneity in the analysis of data. About the former, to measure the tightness of the VaR constraint I use a dataset of daily $\mathrm{VaR}$ and VaR limits of Italian banks, retrieved from supervisory reporting data. For the latter, to take into account any potential endogeneity of the data, a vector autoregression model (VAR) without contemporaneous components has been employed. In addition, the measures of banks' VaR (based on historical worst $1 \%$ of losses) and market risk (volatility of returns) have been based on two neatly distinct variables (historical simulation VaR versus standard deviation of returns). Lastly, I do not use as a variable a simple measure of market risk, such as VaR, but a measure of tightness of the regulatory constraint ("VaR ratio", which is the ratio between $\mathrm{VaR}$ and internal risk limit), which has low correlation with the market risk measure (volatility of the stock exchange index).

With this framework in mind, I find that market volatility has a significant, positive relation with lagged $\mathrm{VaR}$ ratio (one lag), in line with the amplification effect described in literature. Furthermore, I find also evidence of the overshooting effect described by Shin (2010), since the VaR ratio at lag two has a negative impact on market volatility.

Despite the relevant number of theoretical articles on risk management and procyclicality, this is the first empirical investigation that uses jointly internal data from bank and financial markets to prove the existence of the macro-impacts of VaR.

The results provide additional keys to interpret the recent reaction of the European supervisor to the pandemic crisis, further suggestions to study the unintended consequences of individual regulatory instruments, and evidence of the mechanism that takes place when a measure used to control and contain the risk of individual financial agents has an impact on the whole system and on market variables (such as prices, returns and volatility), via the homogenization of behaviours.

The article is organized as follows: Sect. 2 provides a literature review, of theoretical and empirical articles, Sect. 3 explains the main methodological choices, Sect. 4 describes the data used, Sect. 5 presents the major results and proves their robustness. At last, Sect. 6 concludes.

\section{Theoretical background}

Value at risk may be seen as the gold standard among the measures of market risk. Since 1994, when a technical document of JP Morgan-Riskmetrics was released, it has become a standard method to measure downside risk of banks and investment firms. In 1996, an additional boost to the diffusion of VaR as a risk measure came from the Bank of International Settlements (BIS) that considered value at risk 
methodologies as acceptable from a regulatory point of view (Basel Committee on Banking Supervision, 1996). Since then, VaR-type measures have gained even more favour among financial intermediaries. In fact, VaR is easy to understand (it is measured in price units, such as dollars or euros, or as a percentage of portfolio value), it can be used to compute and compare risk of different types of assets and various portfolios, and it can be used to allocate capital to different units, even if it is not easily additive. Therefore, from the point of view of financial intermediaries (individual view), VaR is a good instrument to measure and compare market risk of their investments and it is currently adopted also by small banks to manage their exposure to market risk.

However, from a systemic point of view (systemic view), VaR and other risk management measures may homogenize the behaviours of financial agents, thus amplifying the cycle. These critiques, mostly theoretically founded but not empirically proven, are based on the idea that market volatility (seen as a market risk measure) is endogenous in the sense that it depends on the behaviour of market players and on the interaction among them. In particular, in bad times, the use of common risk management techniques, such as VaR, increases the similarity of behaviours of different investors, such as banks, so causing unintended and unpredictable effects on the system as a whole. In fact, especially in periods of financial turmoil, market volatility increases and consequently VaR goes up. If the VaR rises excessively, banks sell (or even fire sell) some of their financial assets to reduce the risk. Such sales cause further oscillations (increase of volatility) of the prices of listed securities and, consequently, create an additional rise of VaR, so triggering a vicious circle and fostering pro-cyclicality. The vicious circle and the pro-cyclicality effect could be particularly intense if the number of banks using VaR and holding securities in common is high.

More generally, Panetta and Angelini (2009) showed that many variables (e.g. capital regulation, accounting standards and managers' incentives) might have a procyclical impact. In fact, several studies highlight that different mechanisms may foster pro-cyclicality: Adrian and Shin (2006) found a relevant role on pro-cyclicality of the mechanism of targeting the leverage level by market agents and suggest that some micro-behaviours which have macro-impact (e.g. the use of the VaR model to determine internal capital allocation) may have the same vicious effect. In addition, Fiordelisi and Marqués-Ibañez (2013) underlined that prudential regulation, when oriented more to individual banks than to the financial system, may not give the right relevance to the possible systematic impact (also on financial markets) of banks' risks. In 2010, Adrian and Shin claimed that also some accounting rules contribute to increased turmoil: in particular, the mark-to-market principle applied to balance sheets of financial intermediaries along with VaR constraints can foster procyclicality and have an impact on market liquidity and on volatility measures. However, other authors have then shown that prudential regulation has a greater impact on pro-cyclicality than accounting standards (Amel-Zadeh et al. 2014; Brousseau et al. 2014; Jones 2015).

Therefore, in this paper I deal with the pro-cyclical effect of prudential regulation and risk constraints. About this point, Adrian and Boyarchenko (2012), in a model where agents are risk constrained, examined effect of prudential policies on 
the trade-off between system-wide distress and risk pricing. They found that tighter capital requirements successfully shift the term structure of systemic risk downward, but at the cost of an increased price of risk. With specific reference to the impact of market risk constraint (e.g. VaR), also Danielsson et al. (2010) demonstrated that when risk neutral traders operate under value at risk constraints, market conditions exhibit signs of amplification of shocks through feedback effects.

It is worth noting that, still on the impact of market risk constraints on systemic risk, Shin (2010) also showed that the effect on the market can follow a sort of overshooting path (or spiral) featured by an initial excess of reaction and a following convergence towards a new equilibrium. Specifically, he shows that when VaR is less binding (and investors' equity is larger than necessary), investors use the slack capital to purchase additional risky securities so causing an amplified response ("overshooting") to the improvements of fundamentals. Brunnermeier and Pedersen (2009) called "margin spirals" the amplification effect - via feedback—coming from capital constraints.

The above-mentioned papers are mainly theoretical. Empirical literature concerning the impact of regulation and risk limits on market volatility is not extensive. In 2010, in the aftermath of the financial crisis, Wilson et al. (2010) underlined the need for empirical research on how to design regulation to make bank capital less pro-cyclical.

In that period and in the following years, a few papers push forward the knowledge frontier of the empirical research concerning financial pro-cyclicality.

In 2010, Adrian and Shin (2010), on the basis of data of five major US investment banks, showed that financial intermediaries manage their balance sheets actively in a way that causes leverage to be high during booms and low during busts. They concluded that leverage of financial intermediaries is pro-cyclical, because of the active management of balance sheets to respond to changes in prices and measured risk. In their regressions, they found that a change in leverage is impacted negatively by lagged changes in VaR and positively by the change of repos. The result was based on quarterly data for a sample period of 15 years ending at the first quarter of 2008. Furthermore, they explored the nexus between deleveraging of the five banks of their sample and volatility of the market by looking at the repo market (weekly data, from 1990 to 2008, from all primary dealers), finding that the growth rate of repos on dealers' balance sheets significantly forecast, with a negative sign, innovations in the market volatility index (VIX). Therefore, the result coming from the two sets of regressions is a sort of indirect and positive relation between lagged change in VaR and innovations in the market volatility index.

In 2014, in the stream of literature regarding price dynamics, Cont and Wagalath (2014) showed that distressed selling (due, for instance, to capital requirements set by regulators) can have an impact on market variances (and covariances). They applied the model to a three-month period immediately after the collapse of Lehman, showing that they could not refute the hypothesis of no liquidation of assets (fire sales); in addition, they found an impact of distressed selling on the variance-covariance matrix.

The above-mentioned papers show that there is no obvious dependant-independent relation between $\mathrm{VaR}$ and market volatility. In fact, by definition, VaR depends 
on market volatility. Conversely, for the research question of the paper, VaR (ratio) may affect volatility. About the second effect (i.e. the impact of risk limit on volatility), Adrian and Shin $(2006,2010,2013)$ showed how the use of risk limits measured in terms of VaR may determine fire sales; Cont and Wagalath (2014) then showed that fire sales may have an impact on market variance and covariance (therefore, in turn, on VaR).

In this article, the relation between the tightness of the banks' VaR constraint (measured as the ratio between VaR and internal limit of VaR, "VaR ratio"), not simply banks' VaR exposure, and market volatility is directly tested. Daily data on value at risk and financial markets are used (450 observations, one-and-a-half year window) and, based on time series techniques, the existence of Granger causality between the VaR ratio and market volatility is verified. Although Granger causality does not imply a true causality relation among variables, it indicates whether one time series is useful in forecasting another, hence the direction of the flow of information. This feature of Granger causality is extremely useful for the goal of this study, which is exactly to examine the flow of information between the risk constraint measure and the volatility of the market and its direction. The methodology used here is different from the one used by Adrian and Shin (2010) which was based on a longer time-span, a lower frequency of data and on two different panel regressions run on two different samples. An additional significant difference from other empirical papers is related to the geographical perimeter of the variables: Adrian and Shin (2010) and Cont and Wagalath (2014) used US data, whereas the focus of this work is on Italian data. This choice is based on the idea that Italian market is not as international as other European (or US) markets. This feature is particularly important for this type of analysis: any empirical analyses of the relation between data coming from national financial intermediaries (i.e. measure of tightness of VaR limits) and the corresponding national financial market variables require to be focused on markets where domestic financial intermediaries may have a relevant impact on the local financial market. In fact, the Italian market is one of the least internationalized among the largest European nations with regards to both stocks and government bonds (the two main components of the portfolio of securities for Italian banks).

For stocks, a report to the European Commission (Observatoire de l'Epargne Europeene Paris, France, 2013) shows that in 2011 (a period immediately before the time window used for the empirical analysis of this work), the Italian Stock Exchange was less internationalized than other large European countries (Spain, France, United Kingdom, Germany) in terms of the share of foreign investment to total market capitalization of the Stock Exchange (see Fig. 1).

With regards to government bonds, an IMF working paper (Andritzky 2012) showed that in 2011 the share of government securities held domestically was higher in Italy than in other large European countries and in the USA (see Fig. 2).

Furthermore, the relation between Italian Stock Exchange and Italian banks, which is a relevant piece of information for this chapter, is stronger than in other countries. Based on the same European report cited before (Observatoire de l'Epargne Europeene 2013), Italian banks hold a higher share of listed companies relative to other large European countries (9\%; against less than 1\% for the UK, 5\% for Germany and $4 \%$ for France). 


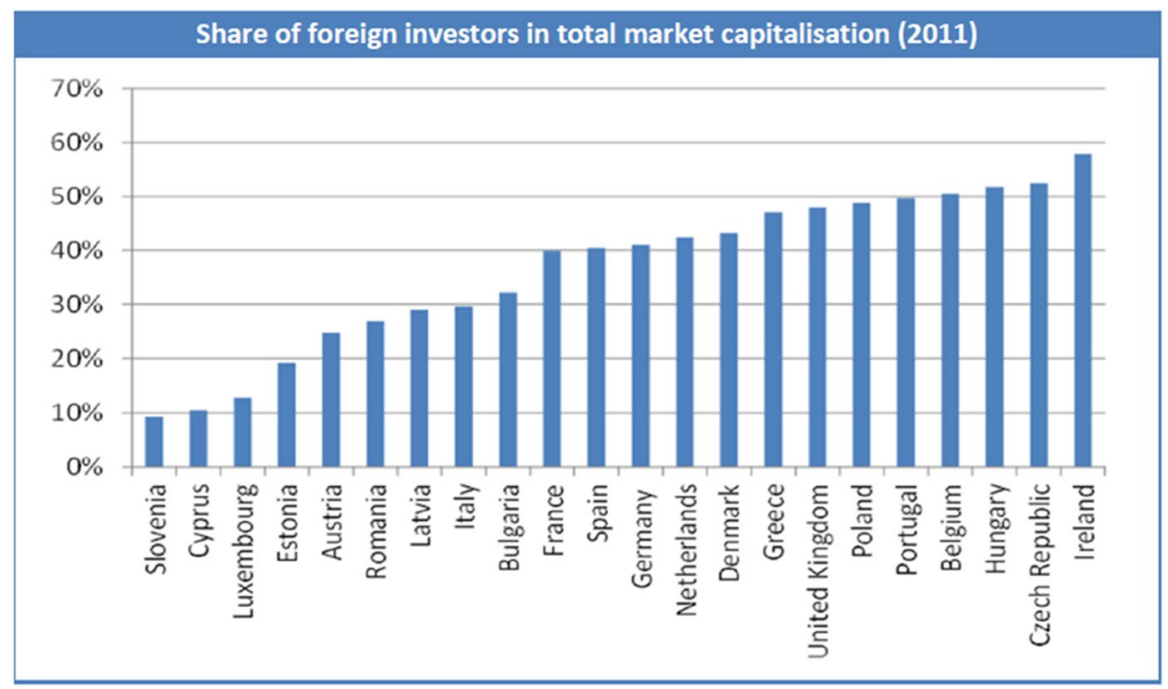

Fig. 1 Foreign investments to total market capitalization. Share of foreign investment investors, as a percentage of total market capitalization per EU country, as of 31 December 2011. Foreign investors are defined as any investors whose residence differs from the registration country of the company whose shares they hold. Foreign investors can be European (other than national) or non-European. Source: Observatoire de 1'Epargne Europeene-OEE (Paris, France) (2013)

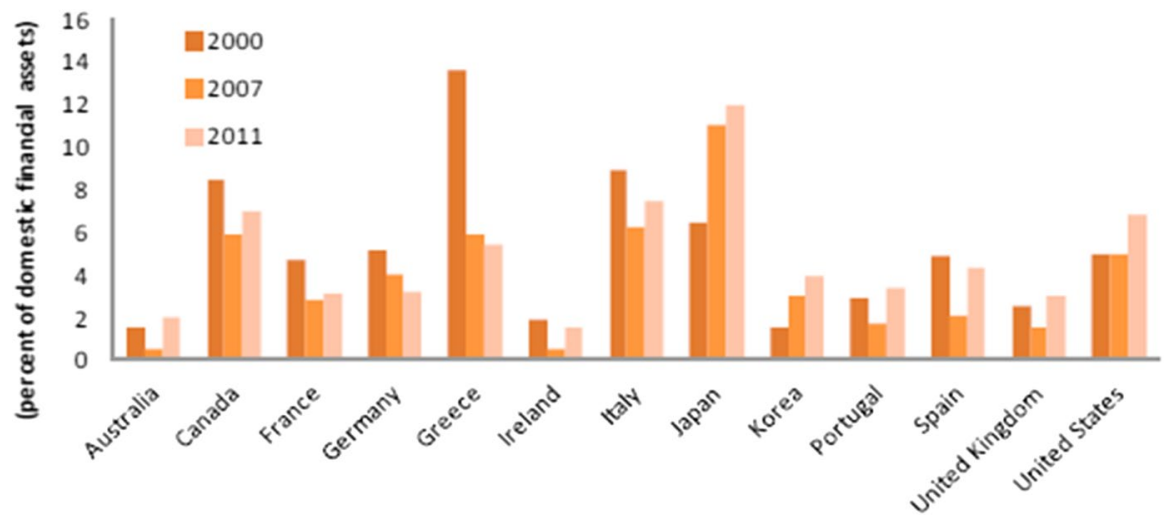

Fig. 2 Government securities held by domestic investors. Portion of domestically held government securities as percentage of total domestic financial assets. Source of the graph: R. Andritzky (2012)

Against this background, the analysis of the relationships between domestic banking data and national financial data for Italy is more significant than for the other above-mentioned countries, where national financial data may also be influenced by the behaviour of non-domestic banks. 


\section{Methodology}

The test of the relation between market volatility and the tightness of the risk limit is based on two major steps. The first step is to compute the volatility of the market; the second step is to examine the relation among market volatility, the VaR ratio and other relevant variables. About the second step, as described in literature (Adrian and Shin 2006, 2010, 2013; Cont and Wagalath 2014) and reported in Sect. 2, there is no obvious dependant-independent relation between VaR and market volatility. This double-way interaction between market volatility and VaR exactly expresses the endogeneity idea, where it is not known exante which variable drives the other, and which one can be considered exogenous.

To deal with such endogeneity (and with the possible reverse causality problem), I opted for the use of the vector-autoregression technique (VAR), where current values of variables are put in relation only with lagged ones (Brooks 2007), without any contemporaneous terms. It is worth noting that, based on the public information published by the major Italian banks, the value at risk model used by banks in the period under analysis was based on historical simulation, not on parametric models. Hence, the VaR definition used in the numerator of the VaR ratio variable is based on the worst $1 \%$ loss level (in a 10-day period) and not on the standard deviation of returns, which is the variable used in the paper to measure market volatility. Thus, the variables used in the regressions (VaR ratio and market volatility) are neatly distinct. Nevertheless, since they refer to similar concepts, in Sects. 5.1 and 5.2 I perform some additional tests on the VaR ratio variable to further check the robustness of the results obtained in the baseline regressions. About the VAR methodology, in the limited number of empirical research articles on the impact of value at risk, this econometric approach has not been used. I opted for this approach not only to deal with endogeneity but also to test the lead-lag relations among the variables used. In Sect. 5.2, some specific robustness tests are performed to control for possible concerns related to the use of VAR (e.g. lag order selection).

The VAR methodology is widely used in literature to test lead-lag relations among variables. Lafuente-Luengo (2009) used it to find evidence of the intraday lead-lag relationship between futures market volatility and spot market volatility; Bec and Gollier (2009), with the same econometric technique, showed that VaR is influenced by the state of the financial market cycle and Chomicz-Grabowska and Orlowski (2020) examined the dynamic interactions between financial market risk (VIX) and some key macroeconomic stability variables with the application of a VAR. However, also due to the lack of public datasets concerning VaR and VaR limits for banks, VAR has not been used in literature for testing the relation between the VaR constraint and market volatility.

Finally, in the VAR framework used in this chapter, also a variable regarding Italian government bonds has been considered as a regressor; in fact, Italy's government bonds greatly affected the Italian financial market in the period examined.

\subsection{Volatility computation and vector autoregression}

The first step of the analysis is the computation of market volatility. In the baseline empirical tests, I use the annualized 10-day volatility of the returns of the market index, in line with the regulatory requirements for VaR (Basel Committee 1996). 
With the second step of the analysis, the relation between market volatility and the VaR ratio of the banks is examined by using a Vector Autoregression technique, where the evolution of each variable is explained based on its own lags and the lags of the other model variables.

In mathematical terms, the VAR model used describes the evolution of a set of $\mathrm{k}$ variables over the same period (with $t$ ranging from 1 to $\mathrm{T}$ ) as a linear function of only their past values. The variables are collected in $\mathrm{k} \times 1$ vector $\mathrm{y}_{\mathrm{t}}$, where the $\mathrm{i}$-th element, $y_{i, t}$, is the observation at time " $t$ " of the $\mathrm{i}$-th variable.

The representation of a VAR is as follows:

$$
y_{t}=\beta_{0}+\sum_{i=1}^{p} \beta_{i} y_{t-i}+\mu_{t}
$$

where $\mathbf{y}_{\mathbf{t}}$ is a $k \times 1$ vector of variables determined by $p$ lags of all $k$ variables in the system, $\mu_{t}$ is a $k \times 1$ vector of error terms, $\beta_{0}$ is a $k \times 1$ vector of constant term coefficients and $\beta_{i}$ are $k \times p$ matrices of coefficients of the i-th lag of $y_{t}$.

Since only lagged values of the variables appear on the right-hand side of the equations, simultaneity is not an issue and OLS yields consistent estimates. To choose the maximum lag $p$ in the VAR model, specific tests are used, as explained in Sect. 5.

All variables have to be of the same order of integration; in detail, to run a VAR in levels all variables have to be $\mathrm{I}(0)$ (stationary). As reported in Sect. 5.1, all variables are stationary or reduced to stationarity therefore an unrestricted VAR in the reduced form is used. In fact, the goal of the chapter is not to study the long-run equilibrium and the related adjustment process (for which VECM would be one of the possible useful approaches), but to examine the lead-lag relation among variables, and to test if the risk constraint (measured with the VaR ratio) does Grangercause the market volatility variable.

\section{Data}

\subsection{Main variables}

In this work, three types of data are used: financial market data; government bond data; measures of the exposure to market risk of some banks.

The main financial market dataset used comes from DataStream and concerns the daily closing prices of the Italian Stock Exchange Index (FTSE MIB). The Italian Index FTSE MIB is a weighted average of the quotes of its components (40 shares). The weights of the components are available on the site of the London Stock Exchange group, of which Italian Stock Exchange is a member. The index accounts for around $80 \%$ of the capitalization of the Stock Exchange.

The government bond data come from Bloomberg and are the daily quotes for the 10 -year Italian government bond and the 10-year German government bond. The Italian government bond yield has become particularly important after the outbreak of the 
sovereign bond crisis, in 2011. Since then, the spread between the yield of the Italian and the German government bonds has become a crucial reference for financial analysts and has been used as a measure of the credit (or sovereign) risk of the country.

Data about banks come from supervisory databases; they measure daily market risk exposure of the Italian banks (i.e. value at risk) using a validated internal model to measure market risk exposure. Banks using a validated internal model are banks authorized to measure their market risk exposure on the basis of internal estimates. In addition to the level of value at risk, supervisory reporting data include also the internal limits of VaR set by every bank for risk management purposes. In this work, the ratio between value at risk level and the internal limit of VaR is used as the measure of the risk constraint impact (VaR ratio). This ratio is computed as the simple average of the VaR ratios of Italian banks, with the assumption that if a bank, whatever its dimension, is close to the VaR limit, it will start to fire sell risky assets thus triggering the amplification effect on market volatility described in literature. The expectations about this variable are that the higher the VaR ratio, the higher the risk incurred relative to the maximum acceptable risk (where the maximum acceptable risk level is the internal limit); therefore, the higher the ratio, the more likely is for banks to sell some financial assets to reduce their risk exposure. Further data on banks (e.g. the securities bought and sold by banks in a certain period), used in this article for descriptive purposes, are from the central bank databases, too.

For all the data mentioned, the time window of the analysis starts from the beginning of April 2012 and ends at the end of December 2013 (see Fig. 3).

I have chosen this time span for four reasons. Firstly, for this period I have a representative sample of banks in the VaR dataset. Secondly, it is a period of high volatility; this higher-than-usual volatility is a good starting point to test the research idea of pro-cyclicality in high-volatility periods caused by the use of regulatory measures. Thirdly, volatility shows both increases and decreases in the period; this is useful in order to test the hypothesis of the article, not only in periods of increase of volatility. Lastly, this period does not include the peak of the second half of 2011, which was more related to specific market risk

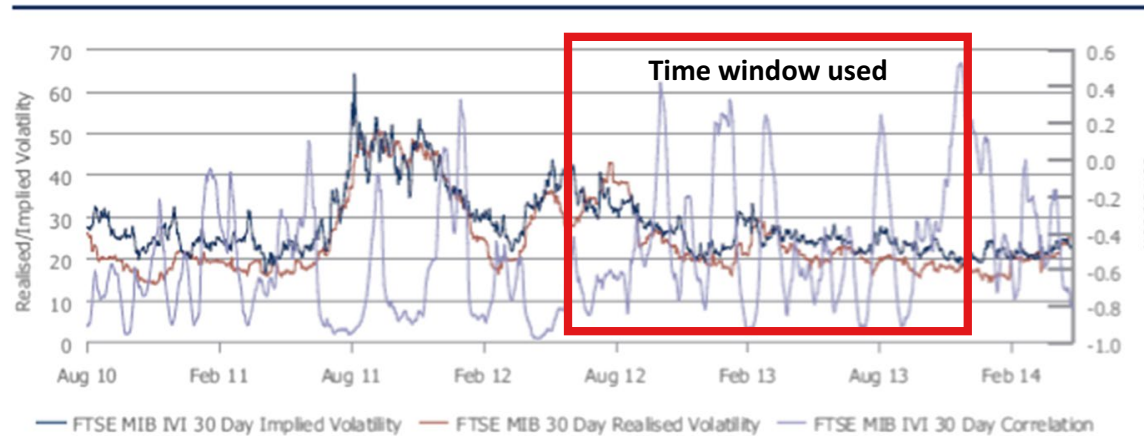

Fig. 3 Volatility in the time window used. Left scale: volatility; right scale: correlation; blue line-realized 30-day volatility; red line-Implied 30-day volatility (implied in options, IVI30, as computed by FTSE). Grey line_right scale, correlation between realized and implied volatility. Source: FTSE (2014) 
(sovereign risk crisis, i.e. issuer risk) than to general market risk; the analysis of specific market risk is beyond the objective of this work.

At last, it is important to note that regulatory market risk exposure, based on $\mathrm{VaR}$, concerns only portfolios held with trading intent.

On this topic, from an accounting perspective, in the period examined IAS 39 was already in force. Therefore, financial instruments held with trading intent were classified under a specific accounting portfolio (held for trading, HFT), measured at fair value with value changes recognised in profit or loss. Other accounting portfolios, not relevant for the analysis, were loans and receivable, held to maturity portfolio (HTM), both carried at amortised cost, and financial instruments available for sale (AFS), measured at fair value with value changes recognised in a non-profit-and-loss item (i.e. other comprehensive income). No movements between two different portfolios were generally allowed and, in fact, in the period under analysis no sample bank changed the allocation of financial instruments held, by moving them to a portfolio different from the one of initial allocation.

From a regulatory point of view, supervisory trading book portfolio (i.e. the relevant portfolio for market risk computation) consists of positions in financial instruments and commodities held either with trading intent or in order to hedge other elements of the trading book, provided that these instruments are free of any restriction on their tradability (Basel Committee on Banking Supervision 2004). This definition was also applicable in Italy in the period under analysis (Banca d'Italia 2012) and is in line with the definition of trading book set in 2013 by EU regulation 575/2013 (Capital Requirement Regulation or "CRR"), which includes in trading book all financial instruments held for trading intent or to hedge positions held with trading intent. Therefore, the definition of supervisory trading book, although grounded on the same concept as HFT portfolio (that is the trading intent), is slightly different from it since it considers hedge positions.

Against this background, for the purpose of the analysis, the relevant portfolio for fire sales is the one on which market risk is computed (i.e. supervisory trading portfolio), as it is the only one with direct impact on supervisory limits on market risk. Furthermore, by limiting the analysis to supervisory trading portfolio, also main alternative strategies to fire sales that banks could implement in case of breach of regulatory limits (i.e. moving financial instruments to nontrading portfolios or hedging market risk of trading positions) are considered. In fact, movements towards other non-trading portfolio were not allowed (and did not happen in the period under analysis) and hedging positions related to HFT instruments were already included in the variable used.

\section{Summary statistics}

By following the methodology described in Sect. 3.1, in order to compute volatility, I preliminarily calculate the returns on the closing price of the FTSE MIB index. In the period examined, the index returns have a mean close to zero and a 
daily standard deviation of $1.6 \%$ (see Table 1 , column a), which is equivalent to an annual volatility of almost $25 \%$.

Public information on risks released by every bank (retrievable from the website of each bank) show that in the sampled period the largest part of market risk was generated by both stocks and Italian government bonds held. In fact, Italian government bonds (BTP, Buoni del Tesoro Poliennali) with fixed rate and medium-long term maturity average around $15 \%$ of the trading portfolio and $35 \%$ of trading activity in the period. As mentioned before, in the period examined government bonds had a large impact on value at risk because of the sovereign risk market crisis started in the second half of 2011.

As in the empirical analysis, I use the sovereign risk variable measured by the spread between Italy and Germany's bonds, in Table 2.1 I also report this variable (column d).

Data on the reference Italian bond show an average yield of $4.8 \%$ with a standard deviation of $0.67 \%$ (Table 1, column c). In the period, the spread with Germany's 10-year bond, which was a proxy of the credit (sovereign) risk for financial investors, has been on average equal to 324 basis points (Table 1, column d). The average exposure of the Italian banks to market risk relative to their own internal limit (VaR ratio) has been around $50 \%$, with a maximum of $74 \%$, and a high range of variability (Table 1 , column $b$ ).

The sample of banks used in this study is representative of the system: the trading activity of these banks accounts for more than $40 \%$ of the negotiations on the components of the stock exchange index and more than $50 \%$ of the trading portfolio of the Italian banking system.

\section{Regressions and results}

As mentioned in the previous section, I test the relation between the Italian market volatility and the VaR ratio.

Table 1 Summary statistics - Italian stock exchange index, value at risk and government bonds

\begin{tabular}{lllll}
\hline Statistics & $\begin{array}{l}\text { FTSE MIB index } \\
- \text { returns } \\
\text { (a) }\end{array}$ & $\begin{array}{l}\text { VaR / internal limit } \\
\text { of VaR } \\
\text { (b) }\end{array}$ & $\begin{array}{l}\text { Yield Gov't } \\
\text { bond } \\
\text { (BTP)(\%) } \\
\text { (c) }\end{array}$ & $\begin{array}{l}\text { Spread Italy- } \\
\text { Germany (basis } \\
\text { points) } \\
\text { (d) }\end{array}$ \\
\hline Mean & 0.00 & 0.51 & 4.79 & 324 \\
Median & 0.00 & 0.50 & 4.54 & 302 \\
Maximum & 0.06 & 0.74 & 6.49 & 523 \\
Minimum & -0.05 & 0.35 & 3.80 & 220 \\
Std. Dev & 0.02 & 0.08 & 0.67 & 76 \\
Number of obser- & 456 & 428 & 440 & 440 \\
vations & & & &
\end{tabular}

Time window from 01 April 2012 to 31 December 2013. Daily observations. Index returns are computed as $\log$ variations of daily closing prices (source DataStream). The ratio between VaR and internal limits is based on supervisory reporting data; the source of government bond data is Bloomberg. BTPs (Buoni del Tesoro Poliennali) are Italian government bonds. 
Table 2 Lag order selection and stationarity tests

\begin{tabular}{|c|c|c|c|c|}
\hline \multicolumn{5}{|l|}{ Lag order selection } \\
\hline \multirow[b]{2}{*}{ Lags } & \multicolumn{2}{|l|}{ VAR Table 3} & \multicolumn{2}{|l|}{ VAR Table 4} \\
\hline & $\begin{array}{l}\text { SIC } \\
\text { (a) }\end{array}$ & $\begin{array}{l}\text { AIC } \\
(b)\end{array}$ & $\begin{array}{l}\text { SIC } \\
(c)\end{array}$ & $\begin{array}{l}\mathrm{AIC} \\
\text { (d) }\end{array}$ \\
\hline Lag 1 & -21.93 & -22.05 & -33.23 & -33.35 \\
\hline Lag 2 & $-21.94^{\S}$ & $-22.16^{\S}$ & $-34.14^{\S}$ & $-34.35^{\S}$ \\
\hline Lag 3 & -21.75 & -22.06 & -33.95 & -34.27 \\
\hline Lag 4 & -21.65 & -22.07 & -33.82 & -34.24 \\
\hline Lag 5 & -21.51 & -22.05 & -33.68 & -34.22 \\
\hline Lag 6 & -21.37 & -22.02 & -33.52 & -34.17 \\
\hline \multicolumn{5}{|l|}{ Stationarity checks } \\
\hline Variable & $\begin{array}{l}\text { Unit root test } \\
(\mathrm{ADF}) \\
(e)\end{array}$ & $\begin{array}{l}\text { Unit root test (PP) } \\
(f)\end{array}$ & $\begin{array}{l}\text { Unit root test on } \\
\text { de-trended vari- } \\
\text { able (ADF) } \\
(g)\end{array}$ & $\begin{array}{l}\text { Unit root test on de- } \\
\text { trended variable } \\
\text { (PP) } \\
\text { (h) }\end{array}$ \\
\hline $\begin{array}{l}\text { Volatility (10- day } \\
\text { returns) }\end{array}$ & -1.49 & $-1.69^{*}$ & $-4.20 * * *$ & $-5.30 * * *$ \\
\hline Spread ITA-GER & -0.78 & -0.82 & $-3.76 * * *$ & $-3.78^{* * *}$ \\
\hline VaR Ratio & -1.12 & -1.40 & $-4.52 * * *$ & $-4.37 * * *$ \\
\hline VaR ratio on HFT & -0.67 & -0.66 & $-12.02 * * *$ & $-12.79 * * *$ \\
\hline $\begin{array}{l}\text { Volatility of the } \\
\text { BTP yield }\end{array}$ & -1.19 & $-1.68^{*}$ & $-3.51 * * *$ & $-4.62 * * *$ \\
\hline
\end{tabular}

Lag order selection: AIC stands for Akaike information criterion, SIC stands for Schwarz information criterion. I limit the analysis to the sixth lag; the result does not change up to 10 lags.

Stationarity checks: null: the variable has a unit root. Columns (e) and (f): tests on the variables, columns (g) and (h): tests on the de-trended, stationary variables (Brooks 2007). ADF (augmented Dickey Fuller) test performed with the automatic lag length selection (based on SIC criterion): PP (Phillips Perron) test based on Bartlett kernel spectral estimation method and the automatic selection (Newey West) for the bandwidth. ${ }^{\S}$ indicates lag order selected by the criterion. ***-significant at 0.01 level, **_-significant at 0.05 level, *-significant at 0.1 level. Number of observations reported in Tables 3 and 4.

To measure market volatility for the baseline results (Sect. 5.1) I use the standard deviation of the market (the annualized 10-day volatility of the returns of the market index, as mentioned in Sect. 3.1). In the analysis of the relation between the Italian market volatility and the VaR ratio, I also control for the impact of the spread between Italian government bonds and the German bonds (hereinafter the spread). In fact, this spread is a measure of sovereign risk that is not of interest for the goal of the research. However, it has to be included in the regression because the risk measured by the spread may have affected the market volatility variable used to measure general market risk. In details, the changes of the spread are funnelled towards the market volatility through two channels. One of the transmission mechanisms of the shock is via the price of the shares of the banks listed in the market: an increase of the spread causes a decrease of the value of the portfolio held by Italian banks (a relevant part of their portfolio consists of BTPs) and, for listed banks, of the value of their shares. In turn, this has an impact on market volatility of the market index 
which, in Italy, is strongly dependant on banks' shares (in December 2013, almost one third of the market capitalization of the index was related to banks). The second transmission channel, which is closer to the mechanisms examined in this paper, is via the risk management techniques (VaR). Since a non-negligible portion of the portfolio held by banks consists of BTPs, a negative shock on BTP price due to the increase of the spread has an impact on VaR and the VaR ratio (since the internal risk limit does not change immediately). Consequently, banks may decide to sell risky financial assets to reduce their market risk exposure, thus fuelling the market instability.

\subsection{Main results}

Before estimating the VAR model, I assess the stationarity of the variables by running the Augmented Dickey-Fuller (ADF) and Phillips-Perron (PP) unit root tests. The results of these tests show that no variables were stationary (at a 5\% level of significance) unless purged from the trend effect (Brooks 2007). Hence, I de-trend the non-stationary variables in order to have all stationary variables in the unrestricted vector autoregressive model (VAR) (see Table 2, columns g and h). In line with literature (Brooks 2007, Lutkepohl 2007, Chomicz-Grabowska and Orlowski, 2020, Ozcicek and McMillin 1999), to calculate the right VAR dimensions (i.e. the best lag order), I use the information criteria, in particular the Schwarz information criterion (SIC). In fact, Lutkepohl (2007) suggests using this criterion if consistency and not forecasting ability is the goal of the econometric test to be run. Since in this chapter I do not use VAR for forecasting, I opt for the SIC as the main criterion to determine the number of lags. This criterion suggests that the optimal number of lags is two. For the sake of completeness, the Akaike information criterion also suggests to use a VAR order equal to two (see Table 2). The resulting model is stable and removes most of the autocorrelation (Lutkepohl 2007). To control for the robustness of the lag order choice, some additional checks are performed in Sect. 5.2.

The results of the regressions (1) are reported in Table 3. Based on the theoretical literature I would expect market volatility to be affected, positively, by the lagged tightness of the VaR constraint, measured by the VaR ratio. In fact, the increase of the tightness variable at time t-1 would cause a sale of risky assets and, in the following period, an increase of market volatility. In addition, on the basis of literature (Shin 2010, see Sect. 2) I would expect an overshooting effect, hence a negative relation between VaR ratio and market volatility at lags longer than one. In fact, such expectations are confirmed (Table 3, column a), as the coefficient of VaR ratio is significant (at 5\%) and positive at lag 1 and significant and negative (at 5\%) at lag 2. In addition, the $\mathrm{VaR}$ ratio and the spread do Granger-cause volatility of the market (at 5\% significance) whereas the market volatility and the spread do not Grangercause the VaR ratio, thus showing that the information flows from the VaR ratio and the spread towards market volatility. As known, Granger causality is not a measure of causality but a demonstration that past values of VaR ratio contain information that helps to predict future volatility, which is in line with the research question of this work. 
Table 3 Vector autoregression volatility, VaR ratio and spread (SIC lag order)

\begin{tabular}{llll}
\hline Variables & $\begin{array}{l}\text { Volatility } \\
(\mathrm{a})\end{array}$ & $\begin{array}{l}\text { VaR ratio } \\
(\mathrm{b})\end{array}$ & $\begin{array}{l}\text { Spread ITA-GER } \\
(\mathrm{c})\end{array}$ \\
\hline Volatility (-1) & $0.954^{* * *}$ & 0.149 & -0.349 \\
& $(0.05)$ & $(0.36)$ & $(0.28)$ \\
Volatility (-2) & -0.049 & -0.010 & $0.529 *$ \\
& $(0.05)$ & $(0.36)$ & $(0.29)$ \\
VaR ratio (-1) & $0.016^{* *}$ & $0.830^{* * *}$ & $0.074^{*}$ \\
VaR ratio (-2) & $(0.006)$ & $(0.05)$ & $(0.04)$ \\
& $-0.018^{* *}$ & $0.09 *$ & -0.05 \\
Spread ITA-GER (-1) & $(0.006)$ & $(0.05)$ & $(0.04)$ \\
& $(0.009)$ & -0.035 & $1.026^{* *}$ \\
Spread ITA-GER (-2) & 0.004 & 0.011 & $-0.089 *$ \\
& $(0.008)$ & $(0.06)$ & $(0.05)$ \\
Constant & -0.00 & -0.00 & 0.00 \\
& $(0.00)$ & $(0.00)$ & $(0.00)$
\end{tabular}

Vector autoregression among the simple average of the VaR ratio (VaR divided by internal limit), the volatility of the returns of the index and the spread between reference government bonds of Italy and Germany. The (-1) and (-2) labels after a variable name stand for lag 1 and lag 2 respectively. Daily data for Italian banks and Italian financial market from April 2012 to December 2013. ***-significant at 0.01 level, **_-significant at 0.05 level, *-significant at 0.1 level. Huber-White robust errors. Number of observations: 383.

From the VAR regressions at least two more results come out, in addition to the significance of the amplification (or pro-cyclical) effect (significance with positive sign of VaR ratio with one lag), the significance of the overshooting effect (significance with negative sign of $\mathrm{VaR}$ ratio with two lags), and the Granger causality. The additional results are the autocorrelation of the variables, widely expected as typical of financial time series, and the impact of the VaR ratio on the spread. About the latter, in column (c) (Table 3) the coefficient of VaR ratio (lag 1) is positive and significant, although at a low level (at 10\%). This result and the sign of the coefficient are in line with the expectations. In fact, the trading portfolio of banks also includes some sovereign bonds; hence, an increase of the tightness of the constraint may cause a sale of sovereign bond to reduce the VaR ratio. In addition, the positive sign of the coefficient is in line with the expectations, since an increase of VaR ratio and the consequent sale of bonds cause a fall of the price of bonds and, therefore, an increase of the yield and of the spread. Therefore, from the regressions there is some evidence that the second transmission channel described in Sect. 5 is active. Finally, the lack of relevant significance of lagged volatility on VaR ratio (Table 3, column b) is an additional piece of evidence of the neat distinction between the two variables used, as reported in the introduction and in Sect. 3.

The results here obtained are completely novel for the empirical literature and are interestingly rich, since they confirm both the amplification and the overshooting effect, finding also a granger-causality between the tightness of the regulatory 
constraint and market volatility. In addition, they show that in a market like the Italian one, where sovereign risk may interact with general market risk, regulatory constraint has an impact also on the sovereign bond market.

However, since the numerator of $\mathrm{VaR}$ ratio is $\mathrm{VaR}$, which is based on expected volatility, the result of the empirical test (i.e. lagged VaR ratio impact on current volatility) may not be the answer to the research question (i.e. if the regulatory risk limits affect market volatility). It may simply be the evidence of the fact that expected volatility (included in the numerator of the VaR-ratio variable) is a good predictor of future market volatility. To control for this concern, in the vector autoregression I substitute the VaR ratio variable with a new variable, calculated as the VaR divided by the amount of the trading portfolio of the bank, as a proxy of supervisory trading book. If the results obtained so far (see Table 3) were simply dependant on the fact that today's VaR contains expectations on future volatility, these new regressions should give the same results as the previous ones. On the contrary, if the previous results were only dependant on the tightness of the VaR constraint, and not just on the expected volatility (included in the numerator), the new variable (VaR on trading portfolio "HFT") would not be significant.

The new vector autoregression (the best lags order is two, based on the SIC criterion, see Table 2 column c), shows no significant correlation between the new VaR variable and volatility (Table 2.4 , column a) nor any Granger causality between the two. Since the only difference between the VaR-variable used in Table 3 (VaR divided by the VaR limit) and the one used in Table 4 (VaR divided by the value of the HFT portfolio) is the denominator, I can conclude that it was exactly the $\mathrm{VaR}$ limit, hence the tightness of the regulatory constraint, and not the VaR itself to determine the significance reported in the column (a) of Table 3. Therefore, the results of Table 3 were not a measure of the predictive ability of the expected volatility (included in the numerator of $\mathrm{VaR}$ ratio) but a measure of the impact of the tightness of the risk limit on market volatility.

\subsection{Robustness tests}

The regressions performed so far are based on two relevant choices: the number of lags for the VAR regressions chosen on the basis of the SIC criterion is correct; the risk of the investment in government bonds is correctly measured by the spread. The first choice is particularly relevant, given the sensitivity of VAR models to the choice of the number of lags. The second choice may cause inconsistent estimations due to the use of inaccurate measures of the phenomenon under analysis, in case an inappropriate variable is chosen.

Therefore, in this section I test if the results hold also under different lags of the variables and with different measures of the risk related to the government bonds.

One of the most debated topics in VAR literature is the lag order selection. Although information criteria are generally used (Brooks 2007; Lutkepohl 2007) to select the lag order of VARs, Lutkepohl suggests a criterion based on the likelihood ratio statistic (sequential modified likelihood ratio). Based on this criterion the best 
Table 4 Vector autoregression - volatility, VaR on HFT and spread (SIC lag order)

\begin{tabular}{llll}
\hline Variables & $\begin{array}{l}\text { Volatility } \\
\text { (a) }\end{array}$ & $\begin{array}{l}\text { VaR on HFT } \\
\text { (b) }\end{array}$ & $\begin{array}{l}\text { Spread ITA-GER } \\
\text { (c) }\end{array}$ \\
\hline Volatility (-1) & $0.949^{* * *}$ & 0.000 & -0.362 \\
& $(0.05)$ & $(0.001)$ & $(0.29)$ \\
Volatility (-2) & -0.045 & -0.000 & $0.557^{* *}$ \\
& $(0.05)$ & $(0.001)$ & $(0.29)$ \\
VaR on HFT (-1) & -0.086 & $0.915^{* * *}$ & -2.204 \\
& $(1.96)$ & $(0.03)$ & $(11.63)$ \\
VaR on HFT (-2) & -1.43 & -0.001 & -1.152 \\
& $(1.62)$ & $(0.03)$ & $(9.57)$ \\
Spread ITA-GER (-1) & -0.001 & -0.000 & $1.024^{* * *}$ \\
& $(0.009)$ & $(0.00)$ & $(0.05)$ \\
Spread ITA-GER (-2) & 0.005 & 0.00 & $-0.093 *$ \\
Constant & $(0.009)$ & $(0.00)$ & $(0.05)$ \\
& -0.00 & 0.00 & 0.00 \\
Ven & $(0.00)$ & $(0.00)$ & $(0.00)$
\end{tabular}

Vector autoregression among the simple average of the VaR on HFT (VaR divided by the value of the HFT portfolio), the volatility of the returns of the index and the spread between reference government bonds of Italy and Germany. The (-1) and (-2) labels after a variable name stand for lag 1 and lag 2 respectively. Daily data on Italian banks and Italian financial market from April 2012 to December 2013. $* * *$ - significant at 0.01 level, ** - significant at 0.05 level, * - significant at 0.1 level. Number of observations: 383 .

lag order is five (at 5\% significance level). The model is stable and there is no autocorrelation (at 1\%) up to lag 10.

The results of the regression (1) are reported in Table 5. The expectations are that the amplification (pro-cyclical) and the overshooting effects are confirmed, also with this different lag order. In fact, notwithstanding the higher order and the reduced efficiency of the model (in terms of information criteria), the core results do not change. The VaR ratio with one lag is significant (at 5\%) with the expected positive sign (column a) (amplification effect); the VaR ratio with two lags is negative and significant at 5\% (column a) thus confirming the overshooting effect. In addition, the Granger causality is confirmed.

In addition, as in the baseline results, VaR ratio has a positive and significant effect on the spread variable; with respect to the baseline result, the level of significance is even higher $(5 \%)$.

In sum, this robustness test shows that the results obtained in the baseline scenario are not dependant on the criteria chosen to select the number of lags for VAR. In fact, also with a different lag order, the main results are confirmed, even at a higher level of significance.

As in the previous section, I use the VaR on HFT ratio instead of the VaR ratio as an immediate robustness test of the VaR-ratio variable. As expected, the significance of the VaR variable at lag one fades away (Table 6, column a). The lag order 
Table 5 Vector autoregression volatility, VaR ratio and spread (LR lag order)
Variables

Volatility $\mathrm{VaR}$ ratio

(b)

Spread ITA-GER

(a)

(c)

\begin{tabular}{|c|c|c|c|}
\hline Volatility $(-1)$ & $\begin{array}{l}0.922 * * * \\
(0.054)\end{array}$ & $\begin{array}{c}0.079 \\
(0.403)\end{array}$ & $\begin{array}{l}-0.394 \\
(0.325)\end{array}$ \\
\hline Volatility $(-2)$ & $\begin{array}{l}-0.009 \\
(0.073)\end{array}$ & $\begin{array}{c}0.173 \\
(0.547)\end{array}$ & $\begin{array}{l}0.208 \\
(0.442)\end{array}$ \\
\hline Volatility $(-3)$ & $\begin{array}{c}0.068 \\
(0.072)\end{array}$ & $\begin{array}{c}0.310 \\
(0.540)\end{array}$ & $\begin{array}{l}0.268 \\
(0.436)\end{array}$ \\
\hline Volatility $(-4)$ & $\begin{array}{c}0.022 \\
(0.070)\end{array}$ & $\begin{array}{l}-0.794 \\
(0.524)\end{array}$ & $\begin{array}{l}0.197 \\
(0.423)\end{array}$ \\
\hline Volatility $(-5)$ & $\begin{array}{l}-0.156^{* * *} \\
(0.050)\end{array}$ & $\begin{array}{c}0.306 \\
(0.379)\end{array}$ & $\begin{array}{l}-0.011 \\
(0.306)\end{array}$ \\
\hline VaR ratio $(-1)$ & $\begin{array}{c}0.016^{* *} \\
(0.007)\end{array}$ & $\begin{array}{l}0.816^{* * * *} \\
(0.055)\end{array}$ & $\begin{array}{l}0.093 * * \\
(0.044)\end{array}$ \\
\hline VaR ratio $(-2)$ & $\begin{array}{l}-0.020 * * \\
(0.009)\end{array}$ & $\begin{array}{c}0.025 \\
(0.071)\end{array}$ & $\begin{array}{l}-0.058 \\
(0.057)\end{array}$ \\
\hline VaR ratio $(-3)$ & $\begin{array}{l}-0.003 \\
(0.010)\end{array}$ & $\begin{array}{l}-0.070 \\
(0.072)\end{array}$ & $\begin{array}{l}-0.007 \\
(0.058)\end{array}$ \\
\hline VaR ratio $(-4)$ & $\begin{array}{c}0.007 \\
(0.010)\end{array}$ & $\begin{array}{c}0.183^{* *} \\
(0.071)\end{array}$ & $\begin{array}{l}0.001 \\
(0.057)\end{array}$ \\
\hline VaR ratio $(-5)$ & $\begin{array}{l}-0.002 \\
(0.007)\end{array}$ & $\begin{array}{l}-0.019 \\
(0.055)\end{array}$ & $\begin{array}{l}0.006 \\
(0.044)\end{array}$ \\
\hline Spread ITA-GER (-1) & $\begin{array}{c}0.005 \\
(0.009)\end{array}$ & $\begin{array}{l}-0.027 \\
(0.067)\end{array}$ & $\begin{array}{l}0.994 * * * \\
(0.054)\end{array}$ \\
\hline Spread ITA-GER (-2) & $\begin{array}{c}0.003 \\
(0.013)\end{array}$ & $\begin{array}{c}0.072 \\
(0.095)\end{array}$ & $\begin{array}{l}-0.033 \\
(0.077)\end{array}$ \\
\hline Spread ITA-GER (-3) & $\begin{array}{l}-0.032 * * * \\
(0.013)\end{array}$ & $\begin{array}{l}-0.043 \\
(0.096)\end{array}$ & $\begin{array}{l}-0.079 \\
(0.077)\end{array}$ \\
\hline Spread ITA-GER (-4) & $\begin{array}{l}0.029 * * * \\
(0.013)\end{array}$ & $\begin{array}{l}-0.165^{*} \\
(0.099)\end{array}$ & $\begin{array}{l}-0.078 \\
(0.080)\end{array}$ \\
\hline Spread ITA-GER (-5) & $\begin{array}{c}0.004 \\
(0.009)\end{array}$ & $\begin{array}{c}0.149 * * \\
(0.069)\end{array}$ & $\begin{array}{l}0.132 * * \\
(0.056)\end{array}$ \\
\hline Constant & $\begin{array}{l}-0.000 \\
(0.000)\end{array}$ & $\begin{array}{l}-0.000 \\
(0.001)\end{array}$ & $\begin{array}{l}0.0004 \\
(0.001)\end{array}$ \\
\hline
\end{tabular}

Lag order selected on the basis of the Lutkepohl's LR. Variables: simple average of the VaR ratio (VaR divided the value of the internal limit), volatility of the returns of the index; the spread between reference government bonds of Italy and Germany. The (-1) ... (-5) labels after a variable name stand for lag $1 \ldots$ lag 5 respectively. Daily data on Italian banks and Italian financial market from April 2012 to December 2013. ***_-significant at 0.01 level, **-significant at 0.05 level, *-significant at 0.1 level. Number of observations: 346 . 
suggested by the LR statistics is six; the model remains stable and with no autocorrelation (at $1 \%$ ) up to lag 10 .

For the second robustness test, I test the sensitivity of the result to the spread variable. Hence, I re-perform the VAR tests by substituting the variable spread with a variable more similar to the one used in value at risk model, which is the standard deviation of the volatility of returns of the Italian government bonds. I calculate the change of the daily yield of the BTP and compute the ten-day standard deviation (that is the regulatory time horizon for value at risk). The time series has no unit root, when de-trended.

The results are reported in Table 7 . Even with such a different measure of sovereign risk, the results are in line with expectations and confirm the baseline result. In fact, the VaR ratio stays significant (at 5\%) with the right positive sign at lag one (amplification effect) and the negative sign at lag two (overshooting effect) as reported in column (a) of Table 7; also Granger causality is confirmed.

With respect to the baseline results reported in Table 3, the regressions of Table 7 show an additional, and novel, result. In fact, the impact of the new variable for sovereign risk (i.e. the yield volatility variable) on market volatility is strongly significant at lag two with the expected positive sign (column a). The interpretation of this result, read in conjunction with the impact of VaR ratio on market volatility, is extremely interesting. In fact, the dynamic of the variables seems to be the following: a shock, which increases government yield volatility at time $\mathrm{t}-2$, increases the tightness of VaR constraint at $\mathrm{t}-1$ (VaR ratio) which finally affects volatility, which increases at time t. Such dynamics seem extremely plausible, since an increase of BTP yield volatility which affects VaR ratio may cause a sale of the riskiest assets held in the trading portfolio (possibly shares, so impacting the volatility of the index), to reduce the tightness of the market risk constraint.

The latter result, new with respect to the results reported in Sect. 5.1, brings additional information to interpret the transmission mechanism of shock on the government bond market and the volatility stock exchange index.

\section{Conclusions}

The ECB announcement to reduce capital requirements for market risk to smooth pro-cyclicality, published in April 2020, is a good starting point to discuss the impact of micro-regulation (regulation of single financial intermediaries) on macro behaviour or macro goals (e.g. stability of the financial system).

A large number of theoretical articles (e.g. Danielsson et al. 2004, 2010; Adrian and Shin 2006; Cont and Wagalath 2014) and few empirical papers (e.g. Adrian and Shin 2010) support the existence of an amplification effect on market volatility caused by VaR constraints imposed on individual investors (banks).

In this article I find new empirical evidence concerning the amplification effect of risk limits on market volatility and provide evidence of the existence of Granger-causality flowing from VaR ratio (as a measure of the tightness of VaR limit) of Italian banks and Italian government bonds' spread to the volatility of the index of the Italian financial market. The results are in line with theoretical 
Table 6 Vector autoregression - volatility, VaR on HFT and spread (LR lag order)

\begin{tabular}{|c|c|c|c|}
\hline Variables & $\begin{array}{l}\text { Volatility } \\
\text { (a) }\end{array}$ & $\begin{array}{l}\text { VaR on HFT } \\
\text { (b) }\end{array}$ & $\begin{array}{l}\text { Spread ITA-GER } \\
\text { (c) }\end{array}$ \\
\hline Volatility $(-1)$ & $\begin{array}{l}0.894 * * * \\
(0.055)\end{array}$ & $\begin{array}{l}-0.001 \\
(0.001)\end{array}$ & $\begin{array}{l}-0.359 \\
(0.333)\end{array}$ \\
\hline Volatility (-2) & $\begin{array}{l}-0.009 \\
(0.074)\end{array}$ & $\begin{array}{l}0.001 \\
(0.001)\end{array}$ & $\begin{array}{l}0.277 \\
(0.447)\end{array}$ \\
\hline Volatility (-3) & $\begin{array}{l}0.087 \\
(0.073)\end{array}$ & $\begin{array}{l}0.000 \\
(0.001)\end{array}$ & $\begin{array}{l}0.197 \\
(0.442)\end{array}$ \\
\hline Volatility (-4) & $\begin{array}{l}0.031 \\
(0.072)\end{array}$ & $\begin{array}{l}-0.001 \\
(0.001)\end{array}$ & $\begin{array}{l}0.315 \\
(0.436)\end{array}$ \\
\hline Volatility $(-5)$ & $\begin{array}{l}-0.096 \\
(0.070)\end{array}$ & $\begin{array}{l}0.002 \\
(0.001)\end{array}$ & $\begin{array}{l}-0.774 * \\
(0.426)\end{array}$ \\
\hline Volatility (-6) & $\begin{array}{l}-0.079 \\
(0.052)\end{array}$ & $\begin{array}{l}-0.002 * \\
(0.001)\end{array}$ & $\begin{array}{l}0.719 * * \\
(0.314)\end{array}$ \\
\hline VaR on HFT $(-1)$ & $\begin{array}{l}2.370 \\
(3.326)\end{array}$ & $\begin{array}{l}0.825 * * * \\
(0.056)\end{array}$ & $\begin{array}{l}12.959 \\
(20.016)\end{array}$ \\
\hline VaR on HFT (-2) & $\begin{array}{l}-7.390 * \\
(4.297)\end{array}$ & $\begin{array}{l}0.049 \\
(0.072)\end{array}$ & $\begin{array}{l}-4.633 \\
(25.857)\end{array}$ \\
\hline VaR on HFT $(-3)$ & $\begin{array}{l}4.916 \\
(4.306)\end{array}$ & $\begin{array}{l}-0.035 \\
(0.072)\end{array}$ & $\begin{array}{l}-22.407 \\
(25.910)\end{array}$ \\
\hline VaR on HFT (-4) & $\begin{array}{l}1.218 \\
(4.357)\end{array}$ & $\begin{array}{l}0.097 \\
(0.073)\end{array}$ & $\begin{array}{l}3.063 \\
(26.215)\end{array}$ \\
\hline VaR on HFT $(-5)$ & $\begin{array}{l}-0.708 \\
(3.684)\end{array}$ & $\begin{array}{l}0.013 \\
(0.062)\end{array}$ & $\begin{array}{l}19.588 \\
(22.168)\end{array}$ \\
\hline VaR on HFT (-6) & $\begin{array}{l}-2.111 \\
(1.653)\end{array}$ & $\begin{array}{l}-0.017 \\
(0.028)\end{array}$ & $\begin{array}{l}-9.178 \\
(9.950)\end{array}$ \\
\hline Spread ITA-GER (-1) & $\begin{array}{l}0.003 \\
(0.009)\end{array}$ & $\begin{array}{l}-0.0001 \\
(0.0001)\end{array}$ & $\begin{array}{l}0.989 * * * \\
(0.055)\end{array}$ \\
\hline Spread ITA-GER (-2) & $\begin{array}{l}0.003 \\
(0.013)\end{array}$ & $\begin{array}{l}0.0001 \\
(0.0002)\end{array}$ & $\begin{array}{l}-0.010 \\
(0.077)\end{array}$ \\
\hline Spread ITA-GER (-3) & $\begin{array}{l}-0.026^{* * *} \\
(0.013)\end{array}$ & $\begin{array}{l}-0.000 \\
(0.0002)\end{array}$ & $\begin{array}{l}-0.111 \\
(0.078)\end{array}$ \\
\hline Spread ITA-GER (-4) & $\begin{array}{l}0.026^{* * *} \\
(0.013)\end{array}$ & $\begin{array}{l}-0.0004 * \\
(0.0002)\end{array}$ & $\begin{array}{l}-0.068 \\
(0.080)\end{array}$ \\
\hline Spread ITA-GER (-5) & $\begin{array}{l}-0.010 \\
(0.013)\end{array}$ & $\begin{array}{l}0.0001 \\
(0.0002)\end{array}$ & $\begin{array}{l}0.082 \\
(0.080)\end{array}$ \\
\hline Spread ITA-GER (-6) & $\begin{array}{l}0.012 \\
(0.009)\end{array}$ & $\begin{array}{l}0.0002 \\
(0.0002)\end{array}$ & $\begin{array}{l}0.046 \\
(0.057)\end{array}$ \\
\hline Constant & $\begin{array}{l}-0.000 \\
(0.000)\end{array}$ & $\begin{array}{l}0.000 \\
(0.000)\end{array}$ & $\begin{array}{l}0.000 \\
(0.000)\end{array}$ \\
\hline
\end{tabular}

Note. VAR among the simple average of the VaR divided by the HFT portfolio, the volatility of the index returns and the spread between Italian and German government bonds. The (-1) ... (-6) labels stand for lag 1 ... lag 6 respectively. Daily data on Italian banks and Italian financial market from April 2012 to December 2013. ***_-significant at 0.01 level, **_-significant at 0.05 level, *_-significant at 0.1 level. Number of observations: 334 . 
Table 7 Vector autoregression - market volatility, VaR ratio and volatility of the spread

\begin{tabular}{llll}
\hline Variables & $\begin{array}{l}\text { Market volatility } \\
(\mathrm{a})\end{array}$ & $\begin{array}{l}\text { VaR ratio (on } \\
\text { internal limit) } \\
\text { (b) }\end{array}$ & $\begin{array}{l}\text { Volatility of the yield of the } \\
\text { reference Italian government bond } \\
(\mathrm{BTP}) \\
(\mathrm{c})\end{array}$ \\
\hline Market volatility (-1) & $\begin{array}{l}0.942^{* * *} \\
(0.05)\end{array}$ & $\begin{array}{l}0.149 \\
(0.36)\end{array}$ & $\begin{array}{l}-0.083 \\
(0.07)\end{array}$ \\
Market volatility (-2) & -0.035 & -0.053 & 0.033 \\
VaR ratio (-1) & $(0.05)$ & $(0.36)$ & $(0.07)$ \\
VaR ratio (-2) & $0.016^{* * *}$ & $0.835^{* * *}$ & -0.016 \\
BTP Yield Volatility (-1) & $(0.01)$ & $(0.05)$ & $(0.01)$ \\
& $-0.016^{* *}$ & $0.09 *$ & 0.010 \\
BTP Yield Volatility (-2) & $(0.01)$ & $(0.05)$ & $(0.01)$ \\
Constant & $(0.03)$ & 0.220 & $0.968^{* * *}$ \\
& 0.000 & $(0.26)$ & $(0.05)$ \\
& $(0.00)$ & -0.233 & -0.045 \\
\hline
\end{tabular}

Vector autoregression among the simple average of the VaR Ratio (VaR divided by internal limit), the volatility of the returns of the index, and the volatility of the yield of the reference government bonds of Italy. The (-1) and (-2) labels after a variable name stand for lag 1 and lag 2 respectively. Daily data on Italian banks and Italian financial market from April 2012 to December 2013. Huber-White robust errors. $* * *$ - significant at 0.1 level, **-significant at 0.05 level, *-significant at 0.1 level. Number of observations: 383 .

literature and complement the limited existing empirical evidence. As mentioned above, the results of this paper are limited to the Italian market, where the impact of the behaviour of Italian banks on the local stock exchange is more directly visible than in other, more internationalized, financial system such as the US. For the US, literature has found similar results, though in a more indirect way (Adrian and Shin (2010), who used two different regressions).

I also find additional evidence of the overshooting ("spiral") effect of the shocks, highlighted in literature (Shin 2010, Brunnermeier and Pedersen 2009) and confirmation of the impact of sovereign spread on market volatility.

Hence, based on the empirical relation proven in this article, the existence of unintended consequences of VaR constraints is confirmed. In details, VaR measures, used to regulate individual behaviour and to reduce risk of individual banks, have an amplification effect on market volatility. This effect, in turn has an impact on banks' behaviour, since banks could be induced, by the interaction of the increased volatility and tightening risk limit, to fire sell some assets.

These results, based on the analysis of the direct relation between banking and market variables by using some unique datasets, are novel in literature. Furthermore, the consequences of the findings of this article are extremely relevant. From a policy point of view, one of the consequences is that setting limits on market risk in order to contain risks (and losses) of individual banks, if not supplemented with decisions concerning the management of the increase of risks at a macro level, produces the 
unintended effect of increasing market volatility, thus potentially triggering fire sales and increasing losses of banks.

The timing of the results of this article is also appropriate. As stated in the introduction, in April 2020 the ECB banking supervision announced a temporary reduction in capital requirements for market risk to respond to the extraordinary levels of volatility recorded in financial markets since the outbreak of COVID-19 with the aim of smoothing pro-cyclicality. In addition, the recent proposal of the BIS to change market risk rules, to deal with some of the drawbacks of the method (e.g. inability to adequately capture credit risk inherent in trading exposures; incentives for banks to take on tail risk; inability to capture the risk of market illiquidity, Basel Committee on Banking Supervision (2016a) and 2016b), is not in force, yet. Furthermore, this proposal is not directly addressed to face pro-cyclicality. Therefore, the intervention of the supervisor was especially needed.

The results of this paper put in evidence that possible changes to market risk regulation could try to break the relation between individual constraints and market volatility. This result might be reached by using risk limits that are less directly related to market volatility or with rules that can limit or monitor the amplification effect.

At last, from the research side, the results of this article are the first step of a longer process, which has helped to detect the empirical relations among variables. As a following step, a more comprehensive analysis will be required to define a more comprehensive theoretical model describing the channels that cause the empirical dynamics examined in this empirical paper and to offer additional suggestions about the direction to follow to improve regulation and risk management practices.

Acknowledgements I thank Dmitri Vinogradov and Claudia Girardone for their invaluable contribution and support and seminar participants at the Banking research network workshop (Bank of Italy) for useful comments.

Funding no funding received.

Data availability data on financial markets are publicly available.

Code availability Eviews

Declarations

Conflicts of interest/competing interests none.

\section{References}

Adrian T, Boyarchenko N (2012) Intermediary leverage cycles and financial stability. Federal Reserve Bank of New York Staff Reports, August 2012, No 567

Adrian T, Shin HS (2008) In A Beyer, L Reichlin (eds), The role of money-money and monetary policy in the twenty-first century, fourth ECB central banking conference held on 9-10 November 2006. European Central Bank, Frankfurt, pp 299-309

Adrian T, Shin HS (2010) Liquidity and leverage. Journal of Financial Intermediation 19:418-437

Adrian T, Shin HS (2013) Pro-cyclical leverage and value-at-risk. Review of Financial Studies 27(2):373-403 
Amel-Zadeh A, Barth ME, Landsman WR (2014) Does fair value accounting contribute to procyclical leverage? (March 4) Rock center for corporate governance at Stanford University working paper No. 147. http://ssrn.com/abstract=2300497 or https://doi.org/10.2139/ssrn.2300497. Retrieved on 28 March 2020

Andritzky JR (2012) Government bonds and their investors: what are the facts and do they matter? IMF working paper No. 12/158. International Monetary Fund, Washington

Banca d'Italia (2012) Banca d'Italia, Nuove disposizioni di vigilanza prudenziale per le banche, circolare n. 263, updated on 29 May 2012

Basel Committee on Banking Supervision (1996) Amendment to the capital accord to incorporate market risks, January 1996. www.bis.org/publ/bcbs24.pdf

Basel Committee on Banking Supervision (2004) International convergence of capital measurement and capital standards. A revised framework, June 2004. www.bis.org/publ/bcbs107.pdf

Basel Committee on Banking Supervision (2016a) Explanatory note on the revised minimum capital requirements for market risk, January 2016. https://www.bis.org/bcbs/publ/d352_note.pdf

Basel Committee on Banking Supervision (2016b) Minimum capital requirements for market risk, January 2016. https://www.bis.org/bcbs/publ/d352.pdf

Bec F, Gollier C (2009) Term structure and cyclicality of value-at-risk: consequences for the solvency capital requirement. CESifo working paper No 2596. March 2009, available at https://www. cesifo.org/en/publikationen/2009/working-paper/term-structure-and-cyclicity-value-risk-conse quences-solvency. Retrieved on 08 April 2020

Bernanke B (2006) Modern risk management and banking supervision. Speech at the Stonier Graduate School of Banking, Washington, D.C.

Bernanke B (2008) Risk management in financial institutions. Speech at the Federal Reserve Bank of Chicago's Annual Conference on Bank Structure and Competition. Chicago, 15 May 2008 available at https://www.federalreserve.gov/newsevents/speech/bernanke20080515a.htm. Retrieved on 28 March 2020

Brooks R (2007) Power arch modelling of the volatility of emerging equity markets. Emerg Mark Rev 8(2):124-133

Brousseau C, Gendron M, Bélanger P, Coupland J (2014) Does fair value accounting contribute to market price volatility? An experimental approach. Accounting Finance 54:1033-1061

Brunnermeier MK, Pedersen LH (2009) Market liquidity and funding liquidity. Review of Financial Studies 22(6):2201-2238

Chomicz-Grabowska AM, Orlowski LT (2020) Financial market risk and macroeconomic stability variables: dynamic interactions and feedback effects. J Econ Finance 44:655-669. https://doi. org/10.1007/s12197-020-09505-9

Cont R, Wagalath L (2014) Fire sales Forensics: Measuring endogenous risk. Math Financ 26:835-866

Danielsson J, Embrechts P, Goodhart C, Keating C, Muennich F, Renault O, Shin HS (2001) An academic response to Basel II, Special Paper, no 130, LSE Financial Markets Group, ESRC Research Centre, May 2010. Available at https://www.bis.org/bcbs/ca/fmg.pdf. Retrieved on 05 March 2014

Danielsson J, Shin HS, Zigrand JP (2004) The impact of risk regulation on price dynamics. J Bank Finance 28(5):1069-1087

Danielsson J, Shin HS, Zigrand JP (2010) Risk appetite and endogenous risk, Working Paper series n. 2, Discussion Paper n. 647, February 2010, London School of Economics. Available at https://www. fmg.ac.uk/sites/default/files/publications/DP647.pdf. Retrieved on 24 September 2012

ECB - European Central Bank (2020) ECB Banking Supervision provides temporary relief for capital requirements for market risk. Available at https:/www.bankingsupervision.europa.eu/press/pr/date/ 2020/html/ssm.pr200416 ecf270bca8.en.html, retrieved on 25 August 2020

Fiordelisi F, Marqués-Ibañez D (2013) Is bank default risk systematic? J Bank Finance 37(6):2013

FTSE (2014) FTSE Factsheet $30^{\text {th }}$ May 2014, FTSE MIB Implied Volatility Index, FTSE Group. Retrieved 15 May 2016 from https://ftse.com

Jones S (2015) The Routledge companion to financial accounting theory, Ch. 9. Routledge, Abingdon

Lafuente-Luengo J (2009) Intraday realised volatility relationships between the S\&P 500 spot and future market. Journal of Derivatives and Hedge Funds 15:2009

Lutkepohl H (2007) New introduction to multiple time series analysis. Springer, Berlin

Observatoire de l'Epargne Europeene - oee Paris, France (2013) INSEAD OEE data services - Iods Paris, France, August 2013, Final report on: who owns the European economy? Evolution of the 
ownership of EU-listed companies between 1970 and 2012. Submitted to European Commission and Financial services user group. http://ec.europa.eu/internal_market/finservices-retail/docs/fsug/ papers/1308-report-who-owns-european-economy_en.pdf. Retrieved on 04 November 2014

Ozcicek O, McMillin DW (1999) Lag length selection in vector autoregressive models: symmetric and asymmetric lags. Appl Econ 31(4):517-524

Panetta F, Angelini P, Grande G, Levy A, Perli R, Yesin P, Gerlach S, Ramaswamy S, Scatigna M (2006) The recent behaviour of financial market volatility, Bank for International Settlements (BIS), BIS Papers, No 29

Panetta F, Angelini P et al. (2009) Financial sector pro-cyclicality: lessons from the crisis. Banca d'Italia, Occasional Papers Series, number 44, April 2009

Shin HS (2010) Risk and liquidity. Oxford University Press, New York

Wilson J, Casu B, Girardone C, Molyneux P (2010) Emerging themes in banking: Recent literature and directions for future research. Br Account Rev 42(3):153-169

Yellen JL (2010) Macroprudential supervision and monetary policy in the post-crisis world. Speech at the Annual Meeting of the National Association for Business Economics, Denver, CO, October 11, 2010. Bus Econ 46:3-12. https://doi.org/10.1057/be.2010.35

Publisher's Note Springer Nature remains neutral with regard to jurisdictional claims in published maps and institutional affiliations. 